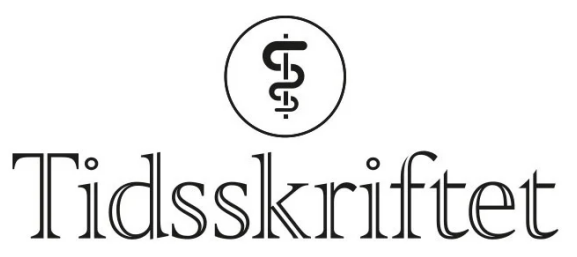

DEN NORSKE LEGEFORENING

\title{
siRNA - fremtidens terapi ved ovarialkreft?
}

MEDISINSK NYTT

ÅSLAUG HELLAND

Email: aslaug.helland@gmail.com

Tidsskriftet

\section{Musestudier gir lovende resultater med bruk av siRNA i behandling av ovarialkreft.}

Ovarialkreft har høy dødelighet. Cellegift har ofte god effekt primært, men kreftcellene utvikler etter hvert resistens mot behandlingen. Nå har forskere undersøkt effektiviteten av lipidoidformulert siRNA mot proteinet claudin-3 i tre musemodeller (1).

Proteinet claudin-3 er overuttrykt i over $90 \%$ av ovarialsvulster og er viktig for kreftcellenes evne til å overleve og spre seg. siRNA er små inhiberende RNA-molekyler som kan slå av uttrykket av bestemte proteiner. Forskerne undersøkte siRNA-molekyler som slo av uttrykket av claudin-3 i musemodeller. Det lipidliknende medikamentet ble injisert intraperitonealt på musene og resulterte i signifikant redusert tumorvekst. I tillegg så man at ascitesproduksjonen ble redusert. Det ble ikke sett toksisitet hos musene.

- I behandlingen av eggstokkreft har vi sannsynligvis nådd så langt vi kan med bruken av tradisjonell kjemoterapi, sier overlege Gunnar Kristensen ved Oslo universitetssykehus, Radiumhospitalet. Det er behov for helt nye medikamenttyper, og videre fremskritt vil være knyttet til bruk av såkalt målrettet behandling, der man griper inn i biologiske prosesser som tumorcellene er avhengige av.

- Det er allerede blitt, og vil fortsatt bli, foretatt en rekke kliniske studier for å vurdere effekten av denne type behandling. Bruken av siRNA i dyremodeller virker såpass lovende at det vil være naturlig å fortsette denne forskningen, slik at man på sikt også kan teste det hos pasienter med eggstokkreft, sier Kristensen.

\section{LITTERATUR}

1. Huang YH, Bao Y, Peng W et al. Claudin-3 gene silencing with siRNA suppresses ovarian tumor growth and metastasis. Proc Natl Acad Sci USA 2009; 106:3426-30.

Publisert: 27. august 2009. Tidsskr Nor Legeforen. DOI: 10.4045/tidsskr.09.0863 
(C) Tidsskrift for Den norske legeforening 2023. Lastet ned fra tidsskriftet.no 26. april 2023. 